\title{
A $20^{\text {th }}$ Century Debate \\ About Imprisonment for Debt
}

\author{
Stephen J. Ware*
}

In the early twentieth century, Parliament debated whether to abolish imprisonment for debt. Parliament's Select Committee on Debtors (Imprisonment) of 1909 heard testimony from witnesses and issued a report recommending the continuation of imprisonment for debt. ${ }^{1}$ This testimony and report make for fascinating history. Although imprisonment is not part of contemporary debates about debt collection and personal insolvency (consumer bankruptcy) law, the competing views expressed in Parliament over a century ago about consumer debtors and those who lend to them will be recognizable to anyone familiar with contemporary debates on either side of the Atlantic.

\section{BACKGROUND}

\section{A. A Brief History}

Imprisonment for debt was, among other things, a method of enforcing English ${ }^{2}$ courts' money judgments. Under the common law "as it existed at the beginning of the thirteenth century, it seems that a man could not be arrested . . . in execution of a judgment, save only in actions of trespass vi et armis." ${ }^{3}$ This was the common law action for injury committed by the defendant with direct force against the plaintiff's person or

\footnotetext{
* Professor of Law, University of Kansas. Thanks to Professors V. Markham Lester, Douglas Baird, John Paul Tribe, David Milman, and Michael Hoeflich for helpful suggestions and to Darin Van Thournout, Tim Bogner, Tyler Manson, Cheri Whiteside, and Todd Burkett for excellent research assistance.

${ }^{1}$ Select Committee on Debtors (Imprisonment), Report and PROCEEDings of the Committee, MiNUTES OF EVIDENCE AND APPENDICES, 1909 (Wyman and Sons, London)[hereinafter The SELECT COMMITTEE].

${ }^{2}$ This article discusses only English law. Regarding imprisonment for debt in the United States, see, for example, PETER J. COLEMAN, DEBTORS AND CREDITORS IN AMERICA: INSOLVENCY, IMPRISONMENT FOR DEBT, AND BANKRUPTCY 1607-1900 (1974); AsA KINNE, THE LAWS OF THE DIFFERENT STATES AND TERRITORIES OF THE UNITED STATES ON IMPRISONMENT FOR DEBT (New York, W.E. Dean, 1842); Charles WARREN, BANKRUPTCY IN United STATES History 52 \& n.8 (1935) (“As late as $1833 \ldots$ it was estimated that 75,000 persons were annually sent to jail for debt," but nearly every state abolished imprisonment for debt by 1857); Joseph Harry Louchheim, The Abolition of Imprisonment for Debt (U. Chicago Masters Dissertation, 1934); BruCE H. MANN, REPUblic of DebTORs: BANKRUPTCY IN THE AGE OF AMERICAN INDEPENDENCE 79 (2002) ("The only consistency among debt laws in the 18th century was that every colony, and later every state, permitted imprisonment for debt."); Charles J. Tabb, The Historical Evolution of the Bankruptcy Discharge, 65 AM. BANKR. L.J. 325 (1991). See also Richard Ford, Imprisonment for Debt, 25 MICH. L. REV. 24, 26 (1926); Comment, Constitutional Law: Imprisonment for Debt, 15 CALIF. L. ReV. 153 (1927). For a discussion of imprisonment for debt in Canada, see Evelyn Kolish, Imprisonment for Debt in Lower Canada. 1791-1840, 32 MCGILL L.J. 603 (1987).

${ }^{3}$ Ford, supra note 2, at 26. Accord 2 ABRAHAM Clark FreEman, LAW of EXeCUTIOns $\S 451,1428$ (Bancroft-Whitney, San Francisco, 1888); Matter of Morris 12 B.R. 330 (1981).
} 
property. ${ }^{4}$ Thus, imprisonment for a judgment debt arising out of this action was probably "a relic of the time when there was no clear distinction between civil and criminal law." Over the next three hundred years or so, imprisonment was extended to more and more actions ${ }^{6}$ until, by the middle of the sixteenth century, it was a remedy available to enforce judgments arising out of a wide variety of actions.'

By the late eighteenth and early nineteenth centuries, approximately 10,000 people (nearly all men ${ }^{8}$ ) were imprisoned for debt each year in England. ${ }^{9}$ During this time period, ${ }^{10}$ many authors-most notably Charles Dickens- "did much to mold public opinion in favor of the abolition of imprisonment for debt."11 The Society for the Discharge and Relief of Persons Imprisoned for Small Debts succeeded in releasing tens of thousands of imprisoned debtors, ${ }^{12}$ further demonstrating that "social opinion was

\footnotetext{
${ }^{4}$ BLACK'S LAW DiCTIONARY 1703-04 (9th ed. 2009).

${ }^{5}$ Ford, supra note 2, at 26-27. "The premodern function of debtors' prison, which lasted long into [the nineteenth century] side by side with its more punitive purpose, was a custodial one. The prison could serve as a not-overly-oppressive haven from one's creditors, a refuge in which a semblance of normal life could be achieved." Dror Wahrman, 46(4) VICTORIAN STUDIES 676, 676-678 (2004) (reviewing MARGOT FinN, The Character of Credit: Personal Debt in English Culture, 1740-1914).

${ }^{6}$ Louchheim, supra note 2, at 3. For a concise history from the $13^{\text {th }}$ through $19^{\text {th }}$ Centuries, see Jay Cohen, The History of Imprisonment for Debt and its Relation to the Development of Discharge in Bankruptcy, $3 \mathrm{~J}$. Legal Hist. 153 (1982). See also Margot Finn, The Character of Credit: Personal DebT in ENGLISH CUlTURE, 1740-1914 110-15 (Cambridge Univ. Press 2003).

${ }^{7}$ Matter of Morris, 12 B.R. 330 (1981).

8 "Although the common-law convention of coverture ensured that relatively few women were confined in their own right as debtors, many chose or were compelled by economic necessity to join their husbands within the prison's walls." FINN, supra note 6, at 132.See also id. at 266.

${ }^{9}$ V. MARKHAM LESTER, VICTORIAN INSOLVENCY BANKRUPTCY, IMPRISONMENT FOR DEBT, AND COMPANY WINDING-UP IN NINETEENTH-CENTURY ENGLAND 97 (1995). One quarter of these were arrested before trial. $I d$.

${ }^{10}$ For other works on the period, see, for example, Cohen, supra note 6; Paul Haagen, Imprisonment for Debt in England and Wales (Princeton U. Doctoral dissertation, 1986); IAN P.H. DUFFY, BANKRUPTCY AND InSOLVENCY IN LONDON DURING THE INDUSTRIAL REVOLUTION (1985); BARBARA WEISS, THE HELl OF THE ENGLISH (1986); Joanna Innes, The King's Bench Prison in the Later Eighteenth Century: Law Authority and order in a London Debtors' Prison, in AN Ungovernable PeOPLE 250-298, (John Brewer and John Styles eds., 1980).

${ }^{11}$ Louchheim, supra note 2, at 26. Numerous pamphlets printed during this period argued, often quite dramatically, against imprisonment for debt. See, e.g., George Brewer, Prospectus of A New LAW BETWEEN DEBTOR AND CREDITOR, WITH REMARKS ON THE INEFFICACY OF IMPRISONMENT FOR DEBT, AND ITS INJURY TO COMMERCE AND TRADE (London, W. Clarke and Sons, 1806); FrEDERIC WILliam NAYLOR Bayley, SCenes and Stories by a Clergyman in DebT. Written DuRing His Confinement IN the DeBToRs' PRISONS (London, A. H. Bailey and Co., 1835); THE BANEFUl EFFECTS OF THE INSOLVENT

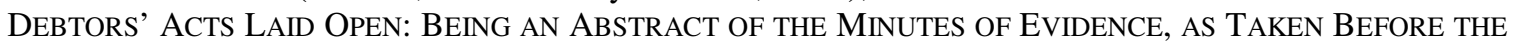

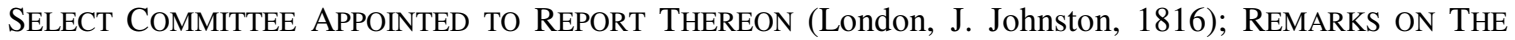
CRUELTY OF THE LAW OF IMPRISONMENT FOR CIVIL DEBT: WITH SUGGESTIONS FOR IMPROVEMENT OF THAT LAW (Edinburgh, Adam \& Charles Black; James Brash \& Co., 1833).

${ }^{12}$ Louchheim, supra note 2, at 23. For an account by the Society's first treasurer, see JAMES NEILD, AN

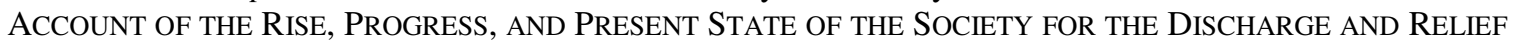
of Persons Imprisoned fOR SMALl DebTs Throughout England AND Wales (Fleet Street, Nichols and Son, 1802).
} 
outraged by [imprisonment for debt] and there was public clamor for reform."13 Parliament responded by passing the Debtors Act of $1869 .^{14}$

The 1869 Act was entitled An Act for the Abolition of Imprisonment for Debt, for the punishment of fraudulent debtors, and for other purposes, and the second clause of the title greatly undercut the first. ${ }^{15}$ While the 1869 Act generally abolished imprisonment for debt, it retained imprisonment as a possibility for "fraudulent" debtors, that is, debtors who did not pay their judgment debts despite having the means to do so. ${ }^{16}$

Section 4 of the 1869 Act generally prohibited imprisonment for debt, providing that "no person shall, after the commencement of this Act, be arrested or imprisoned for making default in payment of a sum of money." However, Section 4 contained two important exceptions, retaining imprisonment for debt. ${ }^{17}$ One exception allowed the High Court, ${ }^{18}$ to imprison a party who did not obey its orders, including orders to pay rates (taxes), maintenance to poor relations, affiliation orders, orders upon parents to maintain children in public institutions, and upon husbands to maintain their wives. ${ }^{19}$ The other important exception in Section 4 of the 1869 Debtors Act allowed imprisonment for "[d]efault in payment for the benefit of creditors of any portion of a salary or other income in respect of which any Court having jurisdiction in Bankruptcy is authorized to make an order." ${ }^{20}$ In sum, Section 4's exceptions pertained to bankruptcy and to non-commercial creditors - the State and the debtor's relatives.

In contrast, the final important exception to the 1869 Debtors Act's abolition of imprisonment for debt pertained to commercial creditors. That final important exception, and the key provision for this article, was Section 5. It stated that

... any court may commit to prison for a term not exceeding six weeks, or until payment of the sum due, any person who makes default in payment of any debt or

${ }^{13}$ Committee on the EnForcement of Judgment DebTs, RePORT, 1969, Cmnd. 3909, at 249 (U.K.).

${ }^{14}$ An Act for the Abolition of Imprisonment for Debt, for the punishment of fraudulent debtors, and for other purposes, 1869, 32 \& 33 Vict., c. 62 (Eng.).

${ }^{15}$ The Act's title was a "cruel and ironic deception." G.R. Rubin, Law, Poverty and Imprisonment for Debt, 1869 - 1914, in LAW, ECONOMY AND SOCIETY 241(G.R. RUBIN \& DAVID SUGARMAN EDS., 1984).

${ }^{16}$ F.H. LAWSON, REMEDIES OF ENGLISH LAW 9 (2d ed. 1980) ("Imprisonment for debt was abolished by the Debtors Act [of] 1869, except where a debtor could but would not pay”); LESTER, supra note 9, at 117 (under the 1869 Act, "[o]nce judgment was entered, courts could imprison a debtor for up to six weeks for a delinquent debt of less than $£ 50$, provided the court found that the debtor failed to pay when it appeared he had the means to do so.").

${ }^{17}$ WALLACE THODAY, IMPRISONMENT BY JUSTICES FOR NON PAYMENT OF MONEY 5 (1936).

${ }^{18}$ For a discussion of the differences between High Court imprisonments and County Court imprisonments under Section 5 of the Debtors Act, see J.D. UnwIN, ThE SCANDAL OF IMPRISONMENT FOR DEBT, 35-38 (1935). For the place of the High Court and county courts in the structure of the English court system today, see, for example, TERENCE IngMAN, THE ENGLiSH LEGAL PROCESS (13th ed. 2010).

${ }^{19}$ Imprisonment on these grounds is discussed extensively in THODAY, supra note 17.

${ }^{20}$ An Act for the Abolition of Imprisonment for Debt, for the punishment of fraudulent debtors, and for other purposes, 1869, $32 \& 33$ Vict., c. $62, \S 4$ (Eng.). For a discussion of relevant bankruptcy law see text infra at notes $27-43$. 
installment of any debt due from him in pursuance of any order or judgment of that or any other competent court.

Provided

(2) That such jurisdiction shall only be exercised where it is proved to the satisfaction of the court that the person making default either has or has had since the date of the order or judgment the means to pay the sum in respect of which he has made default, and has refused or neglected, or refuses or neglects, to pay the same.

Proof of the means of the person making default may be given in such manner as the court thinks just... ${ }^{21}$

In other words, with respect to commercial creditors, the Debtors Act abolished imprisonment for debt except for those judgment debtors who, according to the court's findings, had money but nevertheless refused to pay. ${ }^{22}$ In sum, "[i]t appears from debate in Parliament which gave rise to the Debtors Act 1869, that imprisonment was then retained as the last resort to deal with the recalcitrant debtor.",23

These "can-pay" debtors' refusal to pay was contempt of court. "Technically, the imprisonment was not based upon the debt itself, but rather for contempt of court" 24 - the contempt being failure to comply with the court's order to pay a debt the court believes the debtor is or was able to pay. As Professor Michael Lobban explains, "it was common practice" for courts

to suspend the [arrest] warrant and order payment in instalments on failure of which the warrant would become effective. Although this appeared to be generous to the debtor-allowing him time to pay-it could easily become oppressive, since a suspended warrant of commitment could be activated by any subsequent failure to pay an instalment.

Since it was held that the judge's order of committal related only to the failed instalment, rather than the entire debt, a debtor could be imprisoned for every default in paying an instalment. In the words of Judge Henry Tindal-Atkinson, this created a 'legal thumbscrew' against the debtor. ${ }^{25}$

\footnotetext{
${ }^{21} I d . \S 5$ (emphasis added).

${ }^{22}$ The important practical questions of how courts determined a debtor's ability to pay and how accurately courts made those determinations are discussed below. See infra section VI.

${ }^{23}$ Committee On the Enforcement of Judgment DebTs, supra note 13, at 247. See also Lester, supra note 9, at 101 (most commentators of the period, "saw a difference between the 'honest' and 'dishonest' debtor and believe that only the 'dishonest' debtor should be imprisoned.")

${ }^{24}$ LESTER, supra note 9, at 117. Professor Rubin rejects "the contempt analysis (reasoning which, no doubt, went far to ease the consciences of many creditors and defenders of imprisonment for debt)." Rubin, supra note 15 , at 254. "[W]hereas imprisonment was normally presumed to purge a contempt of court, the Debtors Act explicitly stated that no imprisonment under section 5 (2) was to operate as a satisfaction or extinction of the debt. Logically, therefore, whatever imprisonment was for, it was not for contempt." Id. at 255 .

${ }^{25}$ Michael Lobban, Consumer Credit and Debt, in XII THE OXFORD HISTORY OF THE LAWS OF ENGLAND
} 
Just as this imprisonment was technically for contempt of court, rather than non-payment of the underlying debt, that distinction continues today in contemporary cases incarcerating parties for contempt of court-the contempt being failure to comply with the court's order to pay a debt the court believes the debtor is able to pay. ${ }^{26}$

\section{B. Why Not Bankruptcy?}

Many debtors continued to be imprisoned despite the apparently narrow grounds for which the 1869 Act retained imprisonment as a creditors' remedy. For example, from 1887 to 1891 , "over 30,000 persons went to prison, and of these, over 19,000 stayed in prison the maximum six weeks." 27 In 1904, 11,096 people were committed to prison for nonpayment of debt. ${ }^{28}$

From a contemporary perspective, in which a discharge of debt in bankruptcy is widely available, ${ }^{29}$ one might wonder why any judgment debtor would choose

838 (2010). Accord, Rubin supra note 15, at 256.

${ }^{26}$ See, e.g., Chadwick v. Janecka, 312 F.3d 597, 599 (3d Cir. 2002) ("petitioner has applied eight times to the courts of Pennsylvania and six times to the federal district court for release from incarceration for civil contempt for refusing to comply with an order in a matrimonial proceeding directing him to pay over $\$ 2.5$ million”); Wronke v. Madigan, 26 F. Supp. 2d 1102, 1104 (C.D. Ill. 1998) (affirming continued incarceration of father held in contempt for failure to pay past due child support); State ex rel. Hinckley v. Sixth Judicial Dist. Court, 1 P.2d 105, 108 (Nev. 1931) (ordering contemnor to be held in county jail until fine paid); State ex rel. Phillips v. Knox, No. E2000-02988-COA-R3-JV, 2001 Tenn. App. LEXIS 867, at $* 1-2,34$ (Nov. 29, 2001) (affirming trial court's finding of civil contempt and sentence of thirty days incarceration for failure to pay past due child support); Elizabeth G. Patterson, Civil Contempt and the Indigent Child Support Obligor: The Silent Return of Debtor's Prison, 18 CORNELl J.L. \& PUB. POL'Y 95, 103 (2008) ("Although imprisonment may be imposed, the civil contemnor can secure his release at any time by complying with the order. Hence, it is said that he "carries the keys of his prison in his own pocket."').

${ }^{27}$ LESTER, supra note 9, at 117-18.

${ }^{28} 171$ PARL. DEB., H.C. (4th ser.) (1907) 936 (U.K.).

${ }^{29}$ See, e.g., Donna McKenzie Skene \& Adrian Walters, Consumer Bankruptcy Law Reform in Great Britain, 80 AM. BANKR. L.J. 477 (2006). See also Jacob Ziegel, The Challenges of Comparative Consumer Insolvencies, 23 PENN ST. INT'L L. REV. 639, 649 (2005) (under the English Insolvency Act of 1986 first time bankrupts were entitled to an automatic discharge after three years and the Enterprise Act 2002 reduced the basic discharge period to one year). Id.

Current English law allows discharge of debt both through bankruptcy and other mechanisms. See generally ANDREW R. KEAY \& PETER WALTON, INSOLVENCY LAW: CORPORATE AND PERSONAL, ch.24 (3d ed. 2012); Sue Morgan, NeIl SMyth \& John Tribe, Personal InsolvenCy LaW in Practice (2013); LEN SEALY \& DAVID MiLMan, ANNOTATED GuIDE TO THE InSOlVENCY LEGISLATION (Sweet \& Maxwell Ltd, 16th ed. 2013). Other mechanisms include Individual Voluntary Arrangements ("IVA"s), see, for example STEPHEN LAWSON, INDIVIDUAL VOLUnTARY ARRANGEMENTS (2010), and Debt Relief Orders ("DROs"). See, e.g., David Milman, Debt relief orders: a new option for the distressed individual debtor, 22(10)INSOLVENCY INTELLIGIENCE 153, 153-155 (2009). Bankruptcy requires the debtor have "realisable assets," IVAs require the debtor have continuing income, and DROs require neither. David Milman, Debt relief orders: mixed messages from the courts and policymakers, 25(7) INSOLVENCY INTELLIGENCE 104, 105 (2012). In 2010, England and Wales had 59,194 personal bankruptcies, 50,716 IVAs, and 25,179 DROs. John Tribe, Discharge in bankruptcy: an examination of personal insolvency's fresh start function 
imprisonment over filing for bankruptcy. By the late nineteenth century, English bankruptcy law did allow debtors (including non-merchants) to file for bankruptcy ${ }^{30}$ and receive a discharge of debts.

In England, the principle of a debtor's entitlement to a discharge of his debts in bankruptcy was first recognized in the Bankruptcy Act of 1883. However, it was a long way removed from the American fresh start rule. In particular, the English discharge was subject to the following important qualifications. First, the discharge was in the discretion of the court and, in addition to denying the discharge altogether, the court could issue a conditional or suspended discharge. Second, the debtor had to apply for the discharge and creditors were entitled to oppose it. In the third place, the debtor could be required to make voluntary or court mandated payments to the trustees pursuant to agreement or a court order (income payment order (IPO)). Significantly, the English legislation contained no formula for determining the amount of the IPO but left it to the court's discretion subject to the debtor being left with sufficient income to meet the debtor's essential expenditures for himself, his family and other dependents. ${ }^{31}$

Even if all these obstacles to a discharge of debt in bankruptcy could be overcome by a low-income debtor, another obstacle was emphasized by Parliament's Select Committee on Debtors (Imprisonment) of 1909. According to the Select Committee, a bankruptcy discharge was unavailable to most low-income debtors simply because a debtor's petition for bankruptcy cost ten pounds, which the debtor usually could not afford. ${ }^{32}$

A separate procedure was available to the debtor who owed less than fifty

in English law: part 1, 25(7)INSOLVENCY INTELLIGIENCE 108, 109 (2012).

${ }^{30}$ The first voluntary bankruptcy law in England, enacted in 1844, applied only to traders but was extended to non-merchants in 1861. Charles J. Tabb, The Historical Evolution of the Bankruptcy Discharge, 65 AM. BANKR. L.J. 325, 353-54 (1991) (citing Bankruptcy Act, 1861, 24 \& 25 Vict., c. 134, §§ 69, 86 (Eng.)); LESTER, supra note 9, at 116 ("Parliament . . extended bankruptcy status to non-traders in 1861.") For more detail on the bankruptcy law of the era, see Michael Lobban, Bankruptcy and Insolvency, in XII THE OXFORD HISTORY OF THE LAWS OF ENGLAND, supra note 25.

${ }^{31}$ Ziegel, supra note 29, at 649. See also John Tribe, Discharge in bankruptcy: an examination of personal insolvency's fresh start function in English law:part 2, 25(8) INSOLVENCY INTELLIGIENCE 117, 117-120 (2012); LESTER, supra note 9, at 195 ("the [1883] bill adopted the recommendation of the Lord Chancellor's committee report and provided that no liquidation plan or composition would be valid unless approved by the court.").

32 The Select COMMITTEe, supra note 1, at 280. Accord FinN, supra note 6, at 186 ("As bankruptcy petitions were, for most working-class heads of household, prohibitively expensive, the legislation of 1861 and 1869 effectively restricted imprisonment for debt to the labouring population.”). Inability to afford a bankruptcy petition may be similarly common in the United States today. See Richard M. Hynes, Broke But Not Bankrupt: Consumer Debt Collection in State Courts, 60 FLA. L. REV. 1, 4-6 (2008) (finding that less than twenty percent of Virginia consumers sued in 2001 filed for bankruptcy by 2006 and that nonfiling debtors tend to be poorer than most bankruptcy filers, suggesting that nonfilers may be too poor to file for bankruptcy); Ronald J. Mann \& Katherine Porter, Saving Up for Bankruptcy, 98 GEO. L.J. 289, 290 (2010) (finding that debtors tend to file for bankruptcy when they have saved enough money to pay for bankruptcy attorneys' fees and court costs). 
pounds. ${ }^{33}$ Under Part VII of the Bankruptcy Act of 1883, entitled "small bankruptcies," the County Court would administer the debtor's estate. ${ }^{34}$ The debtor was not required to pay any fee. The court could enter administration orders for "the payment of his debts by installments or otherwise, and either in full or to such an extent as . . practicable, and subject to any conditions as to his future earnings or income which the Court may think just." 35 The debtor's essential property to the value of twenty pounds was exempt and protected from administration orders. ${ }^{36}$ When the court issued an administration order, creditors were deprived of all other remedies against the debtor, but the debtor was not discharged until he had paid (through administration orders) each creditor in full and paid the costs of administration. ${ }^{37}$

Why then, did any debtor go to prison for an unpaid judgment debt, rather than submit himself to the county court's administration orders? ${ }^{38}$ Perhaps because the protection of the county courts' administration procedure was available only when "the debtor [was] unable to pay." 39 It did not protect the only debtor who could legally be imprisoned-the "can-pay" debtor who refused to pay. ${ }^{40}$ Also, bankruptcy administration did not eliminate the possibility of prison. As noted above, failure to pay a bankruptcy administration order was a ground for imprisonment under one of the exceptions in Section 4 of the Debtors Act. ${ }^{41}$ And such imprisonment was not limited to six weeks (as it was for unpaid judgments) but could last a full year. ${ }^{42}$

To recap, at the time of the Select Committee on Debtors (Imprisonment) of 1909, a court could imprison a debtor who failed to pay a bankruptcy administration order or a non-commercial judgment debt for taxes or family support. However, a commercial judgment creditor could only cause a court to issue an order to commit the judgment debtor to prison if it was "proved to the satisfaction of the court that the [judgment debtor] either has or has had since the date of the ... judgment the means to pay." 43 This is the procedure examined by the Select Committee.

\footnotetext{
${ }^{33}$ See Lobban, supra note 25 , at 845.

${ }^{34}$ Bankruptcy Act, 1883, 46 \&47 Vict., c. 52, § 122 (Eng.).

35 Id. The debtor's earnings could also be attached. THE SELECT COMMITTEE, supra note 1, at xviii, (quoting Bankruptcy Act, c. 52).

${ }^{36}$ Bankruptcy Act, c. 52, $\S 122$, sch. 4. ("household goods . . . in the aggregate of twenty pounds, shall to that extent be protected from seizure.").

${ }^{37}$ Id. $\S 122$, sch. 5.

${ }^{38}$ Between 1884 and 1912 an average of only 4954 debtors applied for county court administration orders and this "poor man's bankruptcy system thus played a relatively minor role in debt recovery." Lobban, supra note 25 , at 847 .

${ }^{39}$ Bankruptcy Act, $\S 122$, sch. 1 (emphasis added).

${ }^{40}$ See supra notes 21-23 and accompanying text.

${ }^{41}$ See supra note 20 and accompanying text.

42 An Act for the Abolition of Imprisonment for Debt, for the punishment of fraudulent debtors, and for other purposes, 1869, $32 \& 33$ Vict., c. $62, \S 4$, sch. 6. (Eng.) ("[N]o person shall be imprisoned in any case ... for a longer period than one year .")

${ }^{43}$ Bankruptcy Act, $\S 5$, sch. 2.
} 


\section{The Select Committee}

The Select Committee, which issued its report in 1909, was first appointed on March 19, 1908. ${ }^{44}$ The Parliamentary debate on imprisonment for debt that most closely preceded the appointment of the Select Committee occurred in 1907. ${ }^{45}$ The first Member of Parliament to speak in that debate was Mr. Pickersgill, who would soon be the Chairman of the Select Committee. He called attention to the "steadily increas[ing]" number of persons committed to prison for nonpayment of debt. ${ }^{46} \mathrm{He}$ stated that the number of such people in 1899 was 7,867 but by 1904 had increased to $11,096 .{ }^{47}$ This parliamentary debate resulted in a suggestion by the Solicitor General, Sir W. Robson, that a Select Committee be formed. ${ }^{48}$ Parliament then resolved " $[\mathrm{t}]$ hat the present powers of committing to prison for non-payment of a debt ought to be restricted."

\section{The Select CommitTeE’s Vote AND RePORTS}

For over a year, the Select Committee heard evidence from three-dozen witnesses of diverse backgrounds. ${ }^{50}$ Then on July 27, 1909, the draft reports by Chairman Pickersgill, ${ }^{51}$ and by Mr. Rendall, ${ }^{52}$ were read. As the following pages detail, the Chairman's draft was much more thoroughly opposed to imprisonment for debt than was Mr. Rendall's draft. The Select Committee voted six to five not to reread the Chairman's draft. $^{53}$ As the Select Committee next voted to reread Mr. Rendall's draft which, slightly modified, became the Select Committee's report, ${ }^{54}$ the six-to-five vote was crucial.

The Select Committee consisted of fifteen members, and, as the Chairman votes only in case of a tie, the six-to-five vote reveals that three members were not present for the vote. The importance of those three votes became apparent in a Parliamentary debate during 1914-five years after the Select Committee's report. In response to a suggestion

\footnotetext{
44 See The SELECT COMMITTEE, supra note 1, at iii.

45 171 PARL. DEB., H.C. (4th ser.) (1907) 936-943 (U.K.). See also Lobban, supra note 25, at 841.

46171 PARL. DEB., H.C. (4 ${ }^{\text {th }}$ ser.) (1907) 936 (U.K.).

${ }^{4}$ See id. The accuracy of these figures is supported by the statistics in the THE SELECT COMMITTEE, supra note 1 , at vii. During this era only 5 to 10 percent of those debtors for whom commitment warrants were issued actually ended up in prison. See id. Presumably the remainder paid their debts or escaped from the sheriff. Interestingly, the number of imprisonments for debt plummeted from 11,986 in 1906 to 206 in 1919. See Ford, supra note 2, at 31. These statistics exclude High Court orders for failure to make "alimony and bastardy payments," etc. Id. at 32.

48 171 PARL. DEB., H.C. (4th ser.) (1907) 944 (U.K.).

${ }^{49} I d$.

${ }^{50}$ Professor Rubin writes that some effort was made "to tap [labor] union opinion," but the few representatives of working-class debtors "were pitched into unequal competition with about twenty tradesmen and their representatives pleading the others side." Rubin, supra note 15, at 282. "Evidence conveying the attitudes of the poorer classes directly affected by the Act's operation is thus extremely scarce." Id.

${ }^{51}$ THE SELECT COMMITTEE, supra note 1 , at xi-xxi.

${ }^{52}$ See id. at xxi- xxvi.

${ }^{53}$ See id. at xxvi.

${ }^{54}$ See id. at xxvi-xxix.
} 
that the law relating to imprisonment for debt be amended, the Home Secretary, Mr. McKenna, said that inquiry into the subject was unjustified since the Select Committee had "thoroughly investigated" the subject only five years earlier. ${ }^{55}$ However, Sir W. Byles, one of the three Select Committee members who had missed the key vote, informed the Home Secretary that "in the opinion of a great many persons the Select Committee ... was abortive inasmuch as its Report was contrary to the opinion of the majority of the members of the Committee, several of whom were, unfortunately, absent on the day the Report was adopted."56

That the Select Committee chose Mr. Rendall's draft report over that of the Chairman by such a close vote - a vote that might have gone the other way-shows a sharp division of opinion. The following comparative analysis of the Select Committee's report (the "Report") and the "Chairman's draft" highlights this division and the corresponding divisions in the underlying views of consumer debtors and those who lend to them.

As noted above, governing law at the time of the 1909 Report - the 1869 Debtors Act - provided for imprisonment of only those judgment debtors found by a court to have had, since the judgment, the means to pay the debt. ${ }^{57}$ The Report recommended the continuation of imprisonment of such debtors in the following cases:

- High Court orders to pay taxes, wife and child support, etc., ${ }^{58}$

- administration orders to a debtor under protection of the "small bankruptcies" provisions of the Bankruptcy Act of $1883,{ }^{59}$

- tort judgments, and

- judgments arising out of the debtor's failure to pay for the purchase of "necessaries." 60

The Chairman's draft went further, proposing that imprisonment for debt be entirely "struck out" except for failure to pay taxes, support, ${ }^{61}$ and administration orders in bankruptcy. ${ }^{62}$

\section{NON-CONTRACTUAL DEBTS: TORTS AND SUPPORT ORDERS}

\footnotetext{
55 See 59 PARL. DEB., H.C. (5th ser.) (1914) 424 (U.K.).

${ }^{56} \mathrm{Id}$. at $424-25$.

${ }^{57}$ See supra notes 18-26 and accompanying text.

58 THE SELECT COMMITTEE, supra note 1 , at ix-X.

${ }^{59} \mathrm{Id}$. at ix.

${ }^{60} \mathrm{Id}$. The exception for necessaries was presumably related to the marital law doctrine of necessaries. Based on the husband's duty to support his wife, this doctrine allowed the wife, as the husband's agent, to buy "necessaries" on the husband's credit so the husband would be liable to pay the bill. BLACK'S LAW DICTIONARY 1129 (9th ed. 2009).

${ }^{61}$ THE SELECT COMMITTEE, supra note 1 , at Xx.

${ }^{62} I d$. at xviii.
} 
As just noted, both the Report and the Chairman's draft supported imprisonment of a debtor who did not comply with High Court orders to support his wife or children. ${ }^{63}$ The solicitor general favored imprisonment in these cases because he was reluctant to "deprive the creditor of any remedy" for "debts in which no voluntary credit had been given by the creditor, as in the cases of alimony and bastardy." "64 This distinction between voluntary and involuntary creditors continues to be widespread today, ${ }^{65}$ and also appeared in other portions of the Report and Chairman's Draft. The Report gave an example of a doctor who was not paid for medical treatment by a patient. The Report described the doctor as a creditor whose "credit is compulsorily given" because "the doctor cannot refuse to continue his visits because he is not paid."66

Interestingly, though, the Report and Chairman's draft differed over the classic involuntary creditor-the tort victim. ${ }^{67}$ The Report, but not the Chairman's draft, endorsed imprisonment of a tort judgment debtor who had the means (at some time after judgment) to pay but refused to pay. While the Report and Chairman's draft did not discuss their disagreement over torts generally, the Chairman's draft did discuss the disagreement as to many intentional torts, such as "malicious injuries to person or property." $" 68$ In contrast to the Report, which would allow imprisonment of can-pay intentional tort judgment debtors, ${ }^{69}$ the Chairman's draft wished to abolish imprisonment for these debts entirely. It stated that "these classes of cases properly fall within the criminal law, and ... the criminal law should be strengthened and amended in respect

\footnotetext{
${ }^{63}$ The reason given by the Chairman's draft was that when the debtor refuses to pay a support order, "there is an original wrong done by the debtor, and the imprisonment may be regarded as largely punitive," THE Select Committee, supra note 1, at iv-v. (emphasis added), or as an allied commentator said, "vindictive." Editorial, The Law and the Lawyers), 122 THE LAW TIMES 500 (1907).

${ }^{64} 171$ PARL. DEB., H.C. (4th ser.) (1907) 943 (U.K.) (emphasis added). Accord, UNwIN, supra note 18, at 238.

${ }^{65}$ See, e.g., Peter B. Oh, Veil-Piercing Unbound, 93 B.U. L. Rev. 89, 106 (2013) ("the risk of corporate insolvency simply represents a cost of doing business for voluntary creditors, who have incentives to insure themselves, unlike involuntary creditors, who are victims of unforeseeable harms."); Richard M. Hynes, Non-Procrustean Bankruptcy, 2004 U. ILL. L. REV. 301, 335 (2004) ("In contrast with tort victims and other involuntary creditors, creditors who are in privity of contract with the debtor can adjust their [contract] terms to reflect the possibility of debt relief and thus shift some of the costs of debt relief to the debtor."); Lynn M. Lopucki, The Unsecured Creditor's Bargain, 80 VA. L. REV. 1887, 1963 (1994) ("Involuntary creditors should have priority over voluntary creditors").

${ }^{66}$ THE Select COMMITTEE, supra note 1, at iv-v. Also, emphasizing the distinction between voluntary and involuntary credit is "A County Court Judge", Should Imprisonment for Debt be Abolished? 113 THE LAW TIMES 319 (1902).

${ }^{67}$ See, e.g., Hynes, supra note 32, at 335.

${ }^{68}$ THE SELECT COMMITTEe, supra note 1, at xvi (emphasis in original). In the Parliamentary debate earlier than the Select Committee's, Mr. Pickersgill (who would soon author the Chairman's draft) wished to abolish imprisonment for debt entirely but, as a compromise to secure passage of some legislation, he proposed that it "be retained for debts incurred by fraud and dishonesty and for willful and malicious injuries to property." 171 PARL. DEB., H.C. (4th ser.) (1907) 938 (U.K.).

${ }_{69}$ Those "proved to the satisfaction of the court that the [judgment debtor] either has or has had since the date of the ... judgment the means to pay." An Act for the Abolition of Imprisonment for Debt, for the punishment of fraudulent debtors, and for other purposes, 1869, $32 \& 33$ Vict., c. 62 , § 5 (Eng.).
} 
thereof." 70 So the Chairman's draft would have reduced the tort and crime victim's civil remedies in favor of increased reliance upon the criminal law, while the Report allowed a larger role for private law.

\section{CONTRACTS: NECESSARIES}

In contrast to the non-contractual debts just discussed-support orders and tort judgments-most imprisonments for debt arose out of contracts. Typically, the creditor had lent money or sold goods on credit to the debtor. These consumer-credit transactions became more common in the second half of the nineteenth century as average real incomes rose substantially. $^{71}$

[T]his era [saw] a significant expansion in the number of pawnbrokers, and the development (after the ending of the prohibition on usury in 1854) of money lenders, who lent without security. This era also saw the beginning of hirepurchase, $\left[{ }^{72}\right]$ which by the early twentieth century would supplant pawnbroking as the most important credit mechanism for the poorer consumer. Behind each of these mechanisms stood the county courts, created by legislation in 1846, which acted as an efficient forum of debt recovery. ${ }^{73}$

As noted above, the Report and the Chairman's draft agreed that imprisonment for failure to pay contractual debts should generally be abolished. However, the Report made an exception for necessaries the debtor bought on credit. ${ }^{74}$ Such debtors would continue to be imprisoned if they had the means to pay after judgment but refused to pay. As the Chairman's draft pointed out, the "necessaries" exception was a big exception. Allowing imprisonment for necessaries "would leave entirely untouched the great bulk of the cases; for we have been informed that at least 75 per cent. of the debts put into County Courts are debts owing to the local draper, grocer or baker."75 In short, the Report and Chairman's draft sharply disagreed over imprisoning the debtor who "has or has had since the date of the .. . judgment the means to pay" "76 for the necessaries he, or

\footnotetext{
70 The Select CommitteE, supra note 1, at xvi. The Chairman's draft's support for increased criminalization is further confirmed by its desire "that it should be made a criminal offence for any person having an unsatisfied judgment against him to obtain credit . . . without disclosing the existence of the unsatisfied judgment." This proposal is apparently a response to the charge that, without imprisonment for judgment debts, can-pay debtors will not be sufficiently deterred from borrowing again. The Chairman's draft's confidence in the efficacy of criminalization led it to believe that its above proposal would render the bad-faith debtor "practically disabled from obtaining credit." Id. at xviii.

${ }^{71}$ Lobban, , supra note 25 , at 834.

${ }^{72}$ In the United States, the modern equivalent of hire-purchase is the purchase money security interest. Unif. Commercial Code § 9-103 (2000).

${ }^{73}$ Lobban, supra note 25 , at 834-35.

${ }^{74}$ See supra note 60 and accompanying text.

75 THE SELECT COMMITTEE, supra note 1, at xix.

76 An Act for the Abolition of Imprisonment for Debt, for the punishment of fraudulent debtors, and for other purposes, 1869, 32 \& 33 Vict., c. 62, § 5. (Eng.).
} 
his wife, ${ }^{77}$ purchased on credit.

Both sides of the debate generally agreed that the availability of imprisonment as a remedy for creditors encouraged merchants and "moneylenders" to lend to poor or working class debtors. ${ }^{78}$ The two sides of the debate disagreed about how much credit should be available to these debtors.

Some participants in this debate were eager to reduce the role of credit in "working-class life."79 Before becoming Chairman, Mr. Pickersgill condemned debtors' prisons for "encourage[ing] the pernicious system of credit and the growth of firms whose main business it was to tempt poor people to borrow money at ruinous rates of interest, or to buy articles which they did not want, and which they certainly could not afford to purchase." 80 He referred to such creditors as "tallymen, money lenders, and that class of sharks to whom certain tradesmen sold their debts at about a shilling [to] the pound." " As Chairman, his draft report asserted that without imprisonment "the working man would still obtain quite as much credit as it is good for him to have." 82 In making its case against easy access to consumer credit, the Chairman's draft's concluded that imprisonment "encourages thriftless habits, and by making it easy to obtain credit is really ... a sedative on a man's desire to improve himself. We believe that our proposals [to abolish debtors' prison] will encourage thrift." $" 83$

In contrast, the Report looked more favorably upon easy access to consumer credit. While the Report has some cautions against consumer credit, e.g., "[t]he borrowing of money by impecunious persons is rarely advisable," ${ }^{84}$ most of the Report, in contrast to the Chairman's draft, is very favorable to consumer credit. The Report proudly declared that "[o] ur national life is based almost entirely on a system of credit." 85 In a paragraph entitled "Credit is Based on Character," 86 the Report estimated that "not

\footnotetext{
77 "[U]nder the 'law of necessaries', ... wives enjoyed the right to pledge their husband's credit for 'necessary' (but not 'luxury') goods." FINN, supra note 6, at 14. For further discussion of a husband's liability for his wife's debts, see id. at 266-73.

${ }^{78}$ See, e.g., A County Court Judge, County Courts and Imprisonment for Debt, 123 THE LAW TIMES 533.

79 One believed "[w]hatever tends to substitute credit for cash payment in the small transactions of working-class life is rather to be discouraged than fostered." Id. While the Chairman's draft argued the working class alone suffers the penalty of imprisonment for debt, THE SELECT COMMITTEE, supra note 1, at xii-xiii, the Report claimed to have "had abundant evidence that the richer classes are compelled to pay their debts by its means." Id. at vi.

${ }^{80} 171$ PARL. DEB., H.C. (4th ser.) (1907) 938 (U.K.).

${ }^{81}$ Id. at 937.

${ }^{82}$ The SELECT COMMiTTEe, supra note 1, at xiv. The Chairman's draft asserted that the credit given "to the wage earning classes" is "grossly excessive," supporting this claim with examples of how debtors buy what they do not need and cannot afford. $I d$. at xiii.

${ }^{83} I d$. at $\mathrm{xxi}$ (emphasis in original).

84 "The borrowing of money by impecunious persons is rarely advisable while the temptation held out by money lender and their touts has grown to be enormous." Id. at ix.

${ }^{85} I d$. at ix.

${ }^{86}$ The tenor of this paragraph evokes J. Pierpont Morgan's statement that "a man I do not trust could not get money from me on all the bonds in Christendom." RON CHERnOw, THE House OF MORGAN 154
} 
nearly 5 per cent" of credit transactions come before the courts because creditors diligently investigate the character of the debtor before lending. ${ }^{87}$ But, the Report added, "a credit system is based, amongst other things, on the knowledge of creditors that in ... exceptional cases ... there is power of compulsion [imprisonment]. This power of compulsion therefore assists the giving and receiving of credit to the mutual advantage of giver and receiver in the vast majority of cases." 88

The different views of the Report and Chairman's draft about consumer credit generally were reflected in their specific point of disagreement-imprisonment of those who fail to pay debts incurred in purchasing necessaries despite the means (after judgment) to do so. The Report noted that credit was used extensively by workers to obtain necessaries like clothes, tools and furniture. ${ }^{89}$ It argued that credit was particularly helpful to the working classes, because it enabled workers temporarily unemployed (or underemployed) to get through those periods, repaying the debt "on return to full work." "90 The Report's position is based on the point that some debtors who were able to obtain credit and, therefore, buy necessaries, would not have been able to do so in the absence of imprisonment as a remedy for creditors. ${ }^{91}$ Given that, the Report implicitly argued, if a person is so desperate that he needs credit to buy necessaries, the law ought not to prevent him from obtaining the goods he so desperately needs by depriving him of the only security he can offer to obtain those goods-the possibility of his own imprisonment. $^{92}$

In contrast, the Chairman's draft rejected imprisonment for failure to pay debts incurred purchasing necessaries because "the father who incurs a debt in order to provide food for his starving child,. . . is more deserving of consideration in the eye of the law than the man who recklessly buys a piece of jewellery on credit." 93 But what of the Report's implicit counter-argument that the law was showing consideration for this hypothetical father by allowing him to give the creditor the security that the creditor may have required as a condition of providing food for the child? The Chairman's Draft suggested that other reforms were needed to keep the hypothetical father out of this desperate situation. The Chairman's Draft said that if its proposals "should also 'increase

(1990). A valuable book, FINN, supra note 6. says "Character' serves in the title of this book as a metonym for the fluid constellation of attributes recognised as signifiers of personal credit in the eighteenth and nineteenth centuries." Id. at 18. "By the Victorian period, the idea of character pervaded English society and culture." Id. at 20.

${ }^{87}$ THE SELECT COMMITTEE, supra note 1 , at v.

${ }^{88}$ Id. (emphasis added). See also FINN, supra note 6, at 315 ("tradesmen active in national politics repeatedly - and successfully - [argued] that imprisonment for debt was an essential tool for effecting the transition from status to contract among working-class consumers.")

${ }^{89}$ THE SELECT COMMITTEE, supra note 1 , at v.

${ }^{90} I d$. at ix.

91 See text supra at notes 75-77.

92 "For the debtor who had no assets, no name, or no reputation to post as security and who merely wished a small extension of credit, the possibility of his own imprisonment was the only security he could offer." LESTER, supra note 9, at 121.

93 THE SELECT COMMITTEE, supra note 1 , at xix. 
the agitation for better wages and better methods of legislation against periods of unemployment,' that is not a result which [it was] disposed to deprecate.",94

The above arguments by both sides in this debate over debts incurred to purchase necessaries are, despite the very different context of a century ago, quite similar to contemporary debates about consumer law and unconscionable contracts. ${ }^{95}$ Contemporary advocates of consumer statutes, ${ }^{96}$ and a broad unconscionability doctrine, ${ }^{97}$ seek to protect consumers from harsh terms in their contracts. These advocates are the heirs to the Chairman's Draft. In contrast, the contemporary heirs to the Report argue that enforcing harsh contract terms against consumers who breach them has the desirable effect of lowering prices and thus increasing access to goods and services for the bulk of consumers. ${ }^{98}$

\section{Administrative COSTS}

The Chairman's draft argued that imprisonment for debt had unacceptably high administrative costs - the costs to the state and creditor of committing a debtor to prison. ${ }^{99}$ Regarding the cost to the state, the Chairman's draft met no opposition, as the Report, too, was "much struck by the undue proportion which the costs in respect of judgment summonses and orders of committal bear to the debts to which they relate." "100 The cost to the state of "maintaining debtors in prison frequently exceeded the amount of the debt.",101

As to the cost to the creditor, everyone also seemed to agree that it was too high. As one tradesman complained, "the methods of [imprisonment in] the County Court are

\footnotetext{
${ }^{94} I d$. at xxi.

${ }^{95}$ Professor Rubin sees in this debtors'-prison debate "the concept of law as a mechanism underpinning market exploitation. For what is most interesting, sociologically, is the apparent success of the courts in inculcating a market ideology which also embraced thrift and hard work." Rubin, supra note 15, at 285. The debate between advocates of that ideology and its critics, such as Professor Rubin, continues in our era and it may not be resolved anytime soon.

${ }^{96}$ See e.g., Council Directive 93/13/EEC, Unfair Terms in Consumer Contracts, 1993 O.J. (L 95).; Magnuson-Moss Warranty Act, 15 U.S.C. § 2301 (1975); Unif. Consumer Credit Code.

${ }^{97}$ Williams v. Walker-Thomas Furniture Co., 350 F.2d 445, 449 (D.C. Cir. 1965).

${ }^{98}$ See, for example, Carnival Cruise Lines, Inc. v. Shute, 499 U.S. 585 (1991), in which the Supreme Court enforced a forum-selection clause in a form contract requiring the consumer-plaintiffs, who were from Washington State, to sue in Florida. Id. at 587-88. In enforcing this clause contained in three pages of fine print, the Court cited an opinion by one of the founders of Law and Economics, Judge Richard Posner, for the proposition that "it stands to reason that passengers who purchase tickets containing a forum clause like that at issue in this case benefit in the form of reduced fares reflecting the savings that the cruise line enjoys by limiting the fora in which it may be sued." Id. at 594 (citing Northwestern Nat'l Ins. Co. v. Donovan, 916 F.2d 372, 378 (7th Cir. 1990)).

${ }^{99}$ Additional administrative costs would be incurred under the Report's proposal to retain imprisonment for contractual debts only if for necessaries because courts would need to determine whether something is a "necessary." THE SELECT COMMITTEE, supra note 1, at xix.

${ }^{100} I d$. at viii.

${ }^{101}$ Rubin, supra note 15 , at $251-52$.
} 
costly, uncertain, and painfully slow."102 The Solicitor General referred to the "tedious, costly, and unsatisfactory litigation" needed to make the debtor pay. ${ }^{103}$ Chairman Pickersgill and his allies saw these costs to the creditor as an argument against retaining imprisonment as a remedy for creditors. In contrast, Sir William Bull suggested that if it was costly and time consuming for a creditor to collect a small debt even with the threat of prison, then the law should not become still more onerous to creditors. ${ }^{104}$ The premise of this view - that nearly all the debtors ordered to prison had, as the law required, the ability to pay-is central to the issue discussed in the following section.

\section{JUDICIAL VARIANCE AND ERRORS}

\section{A. How Did Courts Assess a Debtor's Ability to Pay?}

The Report and Chairman's draft expressed competing views about the ability to pay of debtors facing prison. While the 1869 Debtors Act permitted prison only for canpay debtors, ${ }^{105}$ the Chairman's draft argued that judges often mistakenly imprisoned debtors who lacked the ability to pay. ${ }^{106}$ Conversely, creditors complained that judicial errors went the other way in failing to imprison debtors who did have the ability to pay. ${ }^{107}$ Both sides agreed that the law was applied unevenly around the country. The Report $^{108}$ agreed with Chairman Pickersgill's criticism of the "very different standard of

102 The SELECT COMMITTEE, supra note 1 , at xviii.

103 171 PARL. DEB., H.C. (4th ser.) (1907) 943 (U.K.).

${ }^{104}$ See id. at 940-941.

${ }^{105}$ A debtor who "has or has had since the date of the order or judgment the means to pay the sum in respect of which he has made default, and has refused or neglected, or refuses or neglects, to pay the same."An Act for the Abolition of Imprisonment for Debt, for the punishment of fraudulent debtors, and for other purposes, 1869, 32 \& 33 Vict., c. 62, § 5(2) (Eng.).

106 The SElECt COMMitTEE, supra note 1, at xii ("debtors are imprisoned not because they will not, but because they cannot pay.") Accord, Rubin, supra note 15, at 247-48 ("imprisonment continued to remain the punishment for poverty under the [1869] Act.") Similarly, in the contemporary United States imprisonment may still catch debtors who lack the ability to pay.

Non-indigent obligors against whom it is necessary to institute contempt proceedings generally pay the arrearage when threatened with jail. It can reasonably be inferred, therefore, that when large numbers of child support obligors are incarcerated, most are indigent.

This conclusion is further buffered by the facts of appellate cases from throughout the nation that show indigent obligors being jailed for civil contempt with little attention to the economic circumstances underlying their noncompliance.

Patterson, supra note 26, at 118. However, many of the debtors now jailed for civil contempt are held in contempt because of their failure to appear in court rather than their failure to pay. Lea Shepard, Creditors' Contempt, 2011 B.Y.U. L. REV. 1509, 1543-48 (2011).

More and more courts have grown reluctant to use their contempt authority to threaten to imprison even decidedly "can-pay" debtors for failure to comply with courts' directives to turn over money or property to creditors. These courts have concluded that this exercise of their contempt authority is unconstitutional, since it is functionally equivalent to imprisoning debtors for default, a practice illegal in every state.

Id. at 1543-44.

${ }^{107}$ County Court Judge,supra note 78.

108 The SELECT COMMITTEE, supra note 1, at vii-viii. 
the conditions which justified imprisonment [that] seemed to be adopted by different judges." 109

These variances among judges, along with frequent judicial errors, were perhaps both to be expected in light of the "very inadequate means" judges had of discovering what the debtor could afford. ${ }^{110}$ According to one judge,

In one large town the judge has every morning, before the day's work begins, to deal with some thirty or forty or more judgment summonses, and on one specific day in most weeks with between one hundred and two hundred. In very many of these cases there is direct and vigorous conflict of testimony. At great speed he has to determine, as well as he can, which side is telling the truth, or lying the least. ... [A]ll the surrounding issues must be taken into account-age, health, family, former employment, present employment, amount of past or present wages, prospects \&c. The best any judge can do is, with the help of his experience of the parties (many of whom he gets to know), and such common sense and shrewdness as Providence has given him, to make a shot at the right order. ${ }^{111}$

According to another judge, the court took "account of a debtor's obligations to his wife and children" and probably considered his other obligations, the "things necessary for his own decent existence, [and] for . . . earning his livelihood." "112 However, this judge "told the 1909 select committee that he had dealt with 600 applications for imprisonment in a single afternoon and without (for the most part) the presence of the debtor." 113 Debtors "usually remained at work rather than risk the loss of their job" going to court. ${ }^{114}$

In another court, "judgments were made in less than a minute and a half, which hardly left time for consideration of means." 115 "It is absolutely impossible that the County Court can make adequate inquiry into the debtor's ability to pay," argued the Chairman's draft, because the judge simply did not have enough time to thoroughly consider the debtor's means - so courts were bound to make mistakes and imprison those who in fact lacked the means to pay. ${ }^{116}$

109171 PARL. DEB., H.C. (4th ser.) (1907) 936 (U.K.). See also Lobban, supra note 25, at 839-40 ("there was a great deal of variation in practice between the different courts"); Rubin, supra note 15, at 261-66. In criticizing the inconsistent application of the law among different judges, the Chairman's draft noted that in London there was much less imprisonment than in other areas. It suggested two possible explanations for this. One "explanation is that credit is not given, because owing to the huge size of London it is impossible to inquire into the status of the customer, or [the second explanation] that credit is given, but the mobility of the debtor in London renders it impossible to follow him up." THE SELECT COMMITTEE, supra note 1, at xiv.

${ }^{110}$ Lobban, supra note 25 , at 837.

${ }^{111}$ County Court Judge,supra note 78.

112 Judge Cyril Dodd, The Law as to Imprisonment for Debt, 123 LAW TIMES 372 (1907).

${ }^{113}$ Lobban, supra note 25, at 839.

${ }^{114} I d$. at 837 . Rubin, supra note 15 , at 259.

${ }^{115}$ Id. at 837 (citing Paul Johnson, Class Law in Victorian England, PAST \& PRESENT 147, 159 (1993).

116 ThE SELECT COMMITTEE, supra note 1 , at xv. 


\section{B. Imprisoning Debtors Who Lacked the Means to Pay? Or Motivating Their Friends?}

To what extent did courts in fact imprison debtors who lacked the means to pay? Sir William Bull believed that "in 80 per cent. of the committal orders the sums were paid before they were actually enforced," 117 implying that four out of five debtors committed to prison certainly had the means to pay the debt and were holding out until confronted with the threat of imprisonment. ${ }^{118}$ And it was possible that the other one in five also had the means to pay but preferred a short stay in prison to paying off the debt. ${ }^{119}$ Other statistics indicate that over $90 \%$ of committal orders did not lead to imprisonment. ${ }^{120}$ A County Court judge agreed that in the large majority of cases in which a committal order was issued "the result was payment or arrangement before arrest ... so that as a debt-collecting machinery, the system [was] effectual."121

The Chairman's draft conceded that most debtors threatened with prison succeeded in obtaining the money to avoid imprisonment. But the Chairman's draft argued that was because this money was "very generally obtained by [the debtor] either by begging it from his relatives and friends, or by borrowing it from a moneylender at extortionate rates of interest." ${ }^{\text {"22 }}$ The Chairman's draft believed "that if the people who have to pay to keep the debtors out [of] prison are not the debtors themselves, but their friends, the system stands self condemned." 123 In contrast, Lord Bramwell justified the system on this very ground. In Stonor v. Fowle ${ }^{124}$ Lord Bramwell referred to a County Court judge who explained that when he committed debtors to prison for a short period of time they went to prison, but "when they were committed for the whole six weeks they moved heaven and earth among their friends to get the funds to pay."125 Perhaps then, the key dispute in this entire debate was whether debtors' families and friends should be confronted with the choice of paying their relative's or friend's debts or seeing that relative or friend imprisoned. ${ }^{126}$

\footnotetext{
117171 PARL. DEB., H.C. (4th ser.) (1907) 942-943 (U.K.).

118 "Although many debtors who lost their cases in the county courts did not pay up at once, most did before they were gaoled." Lobban, supra note 25, at 837.

${ }^{119}$ See text infra at note 125. It takes "temerity" to make this suggestion, according to The Law and the Lawyers, supra note 63.

${ }^{120}$ See THE SeleCt COMmitTEE, supra note 1, at vii; The Law and the Lawyers, supra note 63.

${ }^{121}$ County Court Judge,supra note 78.

${ }^{122}$ THE SELECT COMMITTEE, supra note 1 , at xiii.

${ }^{123} \mathrm{Id}$.

${ }^{124}$ [1888] 13 AC 20, 29 (U.K.).

${ }^{125} I d$. Despite this anecdote, the Report suggested that maximum imprisonment be reduced from 42 to 21 days. And, in response to fears about the imprisonment of insolvent debtors, the Report recommended that the power to commit be limited to cases in which the debtor had, at the time of the hearing, income above that needed for necessaries. $I d$.

${ }^{126}$ One view on this question is forcefully stated by Professor Rubin: "The State had no interest in inducing a third party to pay a debt due by, for example, a relative to a creditor." Rubin, supra note 15 , at 252 .
} 


\section{ALTERNATIVES TO IMPRISONMENT}

\section{A. Execution against Goods}

In advocating that imprisonment remain a remedy for some commercial creditors, the Report considered alternative means of enforcing judgment debts. The most obvious alternative to imprisonment was execution against the debtor's property. ${ }^{127}$ While the Report argued that imprisonment "causes [the debtor] far less suffering than the breaking up of a home due to the selling of goods under an execution warrant," 128 the Chairman's draft replied that this argument was inconsistent "with the reiterated contention that imprisonment [was] resorted to only when there [were] no goods upon which to levy execution."129 Levying on the debtor's goods, however, is more difficult when the debtor is hiding those goods-so imprisonment may have served primarily as "a powerful engine for extracting from the debtor any property which he had concealed."

Nevertheless, the Report pointed out that even if the creditor could locate the debtor's goods, execution against them was often impossible, either because the goods were owned in the debtor's wife's name or because they were subject to hire-purchase agreements. ${ }^{131}$ "Even the debtor's landlord had a prior claim under the law of distress to the debtor's furniture, allowing him to elbow aside" the judgment creditor seeking to execute on the debtor's goods. ${ }^{132}$ As a result, Professor Gerry R. Rubin states, "there was probably universal agreement even among those opposed to imprisonment for debt that executions were a generally unsuccessful means of debt recovery. For there was generally nothing left to sell after the statutory exemption of the clothes, bedding and tools of the trade." 133 So creditors often argued that "[s]trengthening laws to allow for easier seizure of debtors' assets was of little value"134 to them. With so many debtors lacking significant assets, creditors clung to imprisonment as a remedy to enforce money judgments. As V. Markham Lester explains, a debtor lacking significant assets could offer as security only "the possibility of his own imprisonment.",135

\section{B. Arrestment of Wages}

The problem just noted by Professor Lester-a debtor with insignificant assets

\footnotetext{
${ }^{127}$ See LESTER, supra note 9, at 89 (describing this process as "cumbersome").

128 The Select COMMitTeE, supra note 1, at v-vi. See also Lobban, supra note 25, at 843-44 (citing nineteenth century arguments about whether imprisonment or execution against goods was kinder to debtors).

129 The SELECT COMMITTEE, supra note 1, at Xvii.

130 John Stuart Mill, Principles of Political Economy, 3 Collected Works (U. Toronto, 1965) (quoted in WEISS, supra note 10, at 37.)

${ }^{131}$ THE SELECT COMMITTEE, supra note 1 , at vi.

${ }^{132}$ Rubin, supra note 15 , at 277.

${ }^{133} \mathrm{Id}$.

${ }^{134}$ LESTER, supra note 9, at 121.

${ }^{135} I d$.
} 
had only the possibility of his own imprisonment to offer as security-might have been solved had the law of that era permitted wage arrestment (also known as attachment or garnishment). In 1870, Parliament had abolished wage arrestment in England. ${ }^{136}$ By contrast, the Report said that in Scotland "the threat of an arrestment [was in most cases] sufficient to make the debtor enter into an arrangement acceptable to his judgment creditor."137 But, without explanation, the Report declared that garnishing the debtor's wages "would be undesirable." 138 Some witnesses before the Select Committee testified that working class debtors, more than anyone, would be opposed to arrestment because "they would resent it, and consider it a gross indignity that they should have their wages interfered with." 139 The debtor did not want "his employer to know anything at all about his private affairs." 140

\section{Bankruptcy}

The Report considered bankruptcy as the other alternative to imprisonment in addition to execution against the debtor's goods and arrestment of his wages. In particular, it considered replacing the administration orders of the "small bankruptcies" regime with conventional bankruptcy. However, the Report rejected this idea on the following reasoning.

Bankruptcy is an impracticable remedy in the case of a working man; he has no estate to administer and the disabilities as to status consequent on bankruptcy do not affect him; the existing fee of 10 pounds on filing the petition is also too large a sum for him or his creditor to pay. Further, having obtained credit on the understanding that he should pay his debts out of future earnings it would not be right that he should be able to relieve himself wholly from his debts. Section 122 of the Bankruptcy Act of 1883 [the "small bankruptcies" provision] provides him with a suitable method of releasing himself from his liabilities. ${ }^{141}$

\section{POSTSCRIPT}

Despite the likelihood that, had every member of the Select Committee voted on the Report, it would have called for the abolition of imprisonment for debt, ${ }^{142}$ such abolition did not occur soon after the 1909 Report. In fact, Parliament did not even

\footnotetext{
${ }^{136}$ The Select Committee, supra note 1, at 67 (Sir Kenelm Digby's testimony). See Wages Attachment Abolition Act, 1870, 33 \& 34 Vict. c. 30 (Eng.).

${ }^{137}$ THE SeleCt CommitTEE, supra note 1, at 67 (Sir Kenelm Digby's testimony).

${ }^{138} I d$.

${ }^{139} I d$. at 46 (Mr. Chantler's testimony); id. at 109 (Judge Parry's testimony).

${ }^{140} \mathrm{Id}$. at 46 (Mr. Chantler's testimony).

${ }^{141} I d$. at vi. As noted in the text supra at notes 33-37, under Section 122 where a debtor's debts did not exceed fifty pounds they were consolidated and the debtor paid a sum each month to an officer of the court to be distributed among his creditors. This process continued until all the creditors were paid. Only then was the debtor discharged.

${ }^{142}$ See text supra at note 56.
} 
restrict imprisonment to the extent recommended by the Select Committee's Report. In 1914 Prime Minister Asquith rejected a suggestion for legislation on imprisonment for debt, ${ }^{143}$ and in 1923 Attorney General Bridgeman did likewise because he was "not satisfied that an alteration of the law would be to the benefit of the poorer classes generally.",144

A possible explanation for continuing to allow imprisonment of judgment debtors is simply that it actually occurred less often; the number of such people committed to prisons under Section 5 of the Debtors Act fell from 11,986 in 1906 to only 206 in 1919. ${ }^{145}$ However, "as late as 1929 , the prison commission reported that 3,594 persons lay in prison as a result of failing to pay civil debts.","146

The Select Committee of 1909, which has been the focus of this article, was not the only parliamentary committee to examine imprisonment for debt under the Debtors Act of 1869. The first committee to do so was the Walpole Committee which recommended the abolition of imprisonment for debt in 1873, only four years after the Debtors Act of 1869. ${ }^{147}$ The last committee to examine the issue, and the one that finally persuaded Parliament to end imprisonment for debt, was the Payne Committee of 1966. ${ }^{148}$ Imprisonment for debt under Section 5 of the Debtors Act was abolished in $1970 .{ }^{149}$

143 See 61 PARL. DEB., H.C. (5th ser.) (1914) 1548 (U.K.).

144160 PARL. DEB., H.C. (5 ${ }^{\text {th }}$ ser.) (1923) 1788 (U.K.).

145 See Ford, supra note 3, at 31. See also PATRICK POlden, A History of the County Court, 18461971 App. 3, table 5 (1999). The reduction in the number of debtors imprisoned does not appear to have been caused by a change in the bankruptcy statutes. The Bankruptcy Act of 1914 substantially revised the law but did not affect Section 122 of the Bankruptcy Act of 1883. See Bankruptcy Act, 1914, 4 \& 5 Geo. 5., c. 59, $§ 168$ (Eng.). Thousands of people a year continued to be imprisoned by the High Court. THODAY, supra note 17 , at 7 .

${ }^{146}$ LESTER, supra note 9, at 120.

147 COMMITTEE ON THE ENFORCEMENT OF JUDGMENT DEBTS, supra note 13, at 247.See also Lobban, supra note 25 , at $840-41$.

${ }^{148}$ A 1969 Parliamentary Committee Report stated that between forty and fifty per cent of judgment debts are not enforced. COMMITTEE ON THE ENFORCEMENT OF JUDGMENT DEBTS, supra note 13, at 248.

${ }^{149}$ See id. The Payne Committee cited many of the same arguments that featured prominently in the earlier debates. See id. at 246-261. In 1970, the Administration of Justice Act eliminated the power to commit to prison under Section 5 of the Debtors Act of 1869 with exceptions for such things as maintenance orders and taxes. Administration of Justice Act, 1970, c. 31, 11 (Eng.). See LAwson, supra note 16, at 9 ("By the Administration of Justice Act [of] 1970, which made general the power to attach earnings, imprisonment was further restricted so as to apply only to persons who default in the payment of maintenance and certain rates and taxes.") For a sociological approach to debt collection in that era, see PAul Rock, MAKing PeOPle PAY (1973). For rare contemporary examples of imprisonment for council tax debt, see Rona Epstein, Mothers in prison: the sentencing of mothers and the rights of the child, 17(2) COVENTRY L.J. 2, 20 (2012). 